\title{
THE REPUBLIC OF LATVIA WITHIN THE DIMENSIONAL FRAMEWORK OF INTERNATIONAL LEGAL SUBJECT
}

\author{
Artūrs GAVEIKA \\ Dr. iur., assistant professor at the Faculty of Economics and Management, \\ Rezekne Higher Education Institution, Rezekne, Latvia \\ e-mail: argavs@inbox.lv; phone: +371 29218920
}

\begin{abstract}
In operations of public administration, and especially law enforcement agencies, a particular understanding of the definition of national territory is necessary, especially having in mind the various sovereignty differentiation of national territory into sea areas and airspace, resulting from the modern international and European Union law and which would not be contrary to Article 3 of the Constitution generally determining the meaning of the Latvian State territory. Sometimes the national territory is understood as land or water surface. But setting national borders and border treaties and the national regulatory framework of the state border concept, states include the concept of national borders within their jurisdiction spread in space technical capabilities of land and deep-water in depth and in airspace to the space limit. The main purpose of the research was to analyse the Latvian national framework of legal subject or international and national regulatory frameworks of territory and to offer a clearer and more comprehensive definition of the national territory. The author developed the dimensional framework definition of national territory in the result of research that would be necessary in the national regulatory framework in the context of national security and not in conflict with the international regulatory framework.
\end{abstract}

Keywords: national territory, airspace, the territorial sea, subsoil, jurisdiction JEL code: K33 International Law, Staats Law.

\section{Introduction}

The topicality of the research relates to the concept of national territory, its more exact and clearer definition in the national regulatory framework. The purpose of the paper is to explore the contemporary international regulatory frameworks and judicial practices for a deeper understanding of the concept of the national territory, thereby initiating the discussion about harmonization of the concept in national regulatory frameworks.

The purpose of the research is to analyse the Latvian national framework of legal subject or international and national regulatory frameworks of territory and to offer a clearer and more comprehensive definition of the national territory. To achieve the aim, the following research tasks are set: 1) to explore the national regulatory framework, which refers to the terminology on the national territory; 2) to explore issues of normative regulation of the Latvian national sea areas relating 
to various differentiation of the sovereignty in various jurisdictions of marine areas; 3 ) to explore the Latvian subsoil regulatory framework and its harmonization with international regulatory frameworks; 4) to explore the problems of determination of the Latvian airspace upper limit from the standpoint of international law; 5) to explore the court practice and legal scholars' views on determination of the Latvian border territory; 6) to develop and offer a specific definition of the territory of Latvia as a definition of existential space.

The following scientific research methods are used in the research: a) systematic method; b) grammar method; c) historical method; d) analytical method; f) teleological method.

Research hypothesis: if Latvia as the national territory of international legal subject is specifically defined in the national regulatory framework, it will contribute to the sovereignty of the state and safety in international relations. The research is based on the following sources: books by Bojars, Prescot and others, laws and regulations such as the Convention on International Civil Aviation, the Law On the State Border of the Republic of Latvia and etc., and legal practice materials.

\section{The spatial nature of the national territory}

The national territory is a spatial part of the globe, which is located in a specific national sovereignty and enclosed by its land, sea and air borders. The national territory as a spatial framework includes land, inland and territorial waters, the subsoil below and the airspace above them (Bojars, 2004, p.296). Prof. J.Bojars gives the specific clarifications of included elements for the territory of the State:

1) the land territory includes all state land portions covered by its boundaries (Bojars, 2004, p.307);

2) the sea area consists of its internal (domestic) and territorial waters covered by borders (Bojars, 2004, p.304) or the territorial sea.

Important and noteworthy is Prof. J.Bojars' accentuation of the national territory spatial boundaries and their attribution to the form of segment, because the geometric meaning of the phrase "corresponding to this line vertical surface" in the definition of the concept of national borders as well as in relevant definitions of other countries is incomplete due to the fact that the earth is of spherical shape (although it is slightly stretched in the direction of the equator as a result of the centrifugal force) and the vertical surface of the overlapping state border lines should not be absolutely vertical. In this case, it should be assumed that the country renounces its own significant part of the airspace, but 
perhaps unreasonably another neighbouring state subsoil space is added. Also, the word 'surface' in the definition of the state border is not accurate, because from the geometric terminology point of view it's a plane or nozzle (Cepurniece, Gutmanis, Lukstins etc., 1969, p.585).

Emphasis on national territorial space is also present in the works by other legal scholars, for example, in Prof. R.Cipeliuss' work: "the national territory is not two- but three-dimensional, therefore, it is not the area, but the body located in the space above and below the ground surface layer". Although Prof. R.Cipeliuss did not include the sea (water) areas in this explanation, but hereinafter he reasonably attributed the national territory to the sea as well: "expanding coastal waters to 12 nautical miles, shoreline borders are under the administration of the existing weapons and technical management of marine area borders today. Unlimited territorial sovereignty is up to the baseline, that is, up to the water level line at the low tide line during peak periods" (Cipeliuss, 1998, p.68). In the $19^{\text {th }}$ century's Russian scientists' legal works, the national territory was explained in a spatial meaning, including the land, as well as the sea, i.e. space, which is subject to the National Law (Капустин, 1873, p. 202).

The term 'national territory' is often referred to in international, European Union and national regulatory frameworks, including the National Armed Forces Law (National Armed Forces Law,1999, art. 6, 61), the Law On the State Border of the Republic of Latvia (On the State Border of the Republic of Latvia, 2009, art.1), the Law On Aviation, etc., but none of the laws and regulations, starting with the Constitution of the Republic of Latvia, have a comprehensive and specific definition of the Latvian territory as a state of existence and jurisdiction space.

\section{Latvian sea areas}

The territorial sea of the Republic of Latvia is: a) the waters of the Baltic Sea and of the Gulf of Riga of the Baltic Sea in width of 12 nautical miles (hereinafter - nm), counting from the base line (Law on the State Border of the Republic of Latvia, 2009, art.1, part 10), if it has not been otherwise specified by international agreements; b) the waters of the Gulf of Riga of the Baltic Sea from the base line to the state border determined in accordance with the agreement of the Republic of Latvia and of the Republic of Estonia of 12 July 1996 on maritime demarcation in the Gulf of Riga, the Irbe Strait and the Baltic Sea (Law on the State Border of the Republic of Latvia, 2009, art. 1, part 9).

Such a national regulatory framework regarding sea areas in its entirety conforms to the requirements and concepts of the UN 
Convention on the Law of the Sea (hereinafter - UNCLOS) (United Nations Convention on the Law of the Sea, 1982, art.2).

In the Law on Aviation, the territory of the Republic of Latvia is defined as the land territory of the Republic of Latvia, its internal and territorial waters of the Baltic Sea and airspace (Law On Aviation, 1994, legal terms). In this case, the phrase "the territorial waters of the Baltic Sea" should be defined as "territorial sea" in accordance with UNCLOS terminology. However, in the Treaty on Open Skies the territory of a State Party is considered the land, including islands, as well as internal and territorial waters, which fall within the sovereign territory of the State Party (Treaty on Open Skies, 1992, art. 2).

Therefore, with regard to both national sovereignty and national borders in the context of the concept, it is important to understand the concept of the national territory and its various differentiation of sovereignty, for example, in relation to marine areas.

The provision is not precise in the Marine Environment Protection and Management Law, article 1, paragraph 3: "marine waters of Latvia, as well as natural marine resources, the seabed and the subsoil (hereinafter - the sea) - waters of the Baltic Sea, natural marine resources, the seabed and subsoil in the territory which, in accordance with the national and international legislation, is under the jurisdiction of Latvia, namely, internal marine waters, territorial sea and the exclusive economic zone of Latvia" (hereinafter - EEZ). The phrase "internal marine waters" corresponds neither to the UNCLOS nor to the regulatory framework of Latvia (Law on the State Border of the Republic of Latvia (2009)). In addition, the state jurisdiction regarding the EEZ is limited, and it is specifically provided in Article 56, paragraph 1 of the UNCLOS, which stipulates that the coastal State of the EEZ has sovereign rights only in exploring and exploiting, preserving and managing the natural resources, whether living or non-living, of the waters that cover the bottom of the sea, the seabed and its subsoil.

The Latvian national sovereignty and jurisdictional issues in the Baltic Sea are a topical issue of the contiguous zone. The contiguous zone is regulated as a separate legal institution in article 33 of the UNCLOS. It cannot be extended to the territory that lies further than $24 \mathrm{~nm}$ from the baseline from which a breadth of the territorial sea is measured. However, the contiguous zone of Latvia is referred to and is fixed neither in the Law on the State Border nor in the Marine Environment Protection and Management Law, or elsewhere. Consequently, it is also not intended for the competence of the public administrations in implementation of the Latvian jurisdiction (thus sovereignty) in the contiguous zone. Waters under the jurisdiction of Latvia include the internal waters and territorial 
sea not only within its territory but also in the Latvian EEZ in the Baltic Sea, which is not the Latvian territory, but in which Latvia has prior rights to use natural resources. EEZ, in accordance with Article 57 of the UNCLOS is an area located outside the territorial sea and adjacent to it, and its width should not exceed $200 \mathrm{~nm}$ from the baselines from which the width of the territorial sea is measured. In the EEZ, in accordance with Article 55 of the UNCLOS, it has the right to review the jurisdiction regarding artificial islands and forming the freedom of other structures, exploration by marine science and marine environmental protection. However, other countries of the EEZ has the right to use the freedom of navigation and overflight, submarine cables and freedom to lay pipelines and the rights of use of the sea related to those freedoms. However, other countries need to take into consideration the rights of the coastal State and comply with the certain laws and regulations of the coastal State, such as catch limits and marine environmental protection requirements (Agreement for the implementation of the provisions of the United Nations Convention on the Law of the Sea of 10 December 1982 relating to the Conservation and Management of Straddling Fish Stocks and Highly Migratory Fish Stocks, 1995).

\section{Subterranean depths of Latvia}

Subterranean depths, located below the State land and water areas, are under its jurisdiction as deep in the respective segment as this right can be technically implemented (Bojars, 2004, p.304). The concept of subterranean depths is defined in legal provisions of Latvia, provided that they are a part of the Earth's crust (the Earth's crust - the outer, solid part of the Earth the thickness of which in Latvia is 40-64 km), which is located under the soil, inland and sea water up to the depths in which the use thereof is economically and technically possible (Law On Subterranean Depths, 1996, art. 1, paragraphs 20, 23). The Law on Subterranean Depths defines the rights of the State in the subterranean depths and in the EEZ, and the use of them may be of especial significance in the national economy, protection and in other fields (Law On Subterranean Depths, 1996, art.1, paragraph 19). However, the phrase of the Law On Subterranean Depths 'inland and sea waters' is not exact because in relation to the word 'inland' the legislature apparently refers to internal waters, as defined in the Law on the State Border of the Republic of Latvia (Law on the State Border of the Republic of Latvia, 2009, art.1) and the UNCLOS (United Nations Convention on the Law of the Sea, 1982, art.76, paragraph 5). Regarding national sovereignty in the subterranean depths, an important role is played by the concept of the continental shelf. Certain coastal exclusive rights of the State to explore 
the continental shelf and the exploitation of natural resources are defined in the UNCLOS, moreover, it determines that other countries have no right to explore the continental shelf or exploit its natural resources without certainly expressed approval of the coast State if the coastal State does not do it (Agreement for the Implementation of the Provisions of the United Nations Convention on the Law of the Sea of 10 December 1982 relating to the Conservation and Management of Straddling Fish Stocks and Highly Migratory Fish Stocks, 1982, art. 76-78). In accordance with the UNCLOS, a continental shelf can be no more than $350 \mathrm{~nm}$ from the baseline from which the width of the territorial sea is measured. The rules governing the rights of countries in the continental shelf do not affect the legal status on waters and airspace above those waters. The UNCLOS forbids the coastal State to disturb the freedom of navigation of other countries when it carries the rights over the continental shelf. The continental shelf of Latvia is the seabed surface and the subsoil of underwater areas, which is the Latvian land area of natural sequel, located just behind the territorial sea boundaries of Latvia and extends to specified limits as stipulated in article 3, paragraph 3 of the Marine Environmental Protection and Management Law.

\section{The airspace borders of Latvia}

In accordance with the Convention on International Civil Aviation (ICAO) convention, the national air territory includes the air space above the State and territorial waters located within its sovereign or suzerainty (ICAO, 1944, art.2), not determining the upper border of this space. At the end of the $20^{\text {th }}$ century and at the beginning of the $21^{\text {st }}$ century, the discussion continued and as a result of scientific research, the Space and Earth's atmospheric boundary was declared $100 \mathrm{~km}$ above sea level, which was accepted by the International Aeronautical Federation (Fédération Aéronautique Internationale) and sometimes called the Kármán line (The International Air Sports Federation, 1995).

European Union Regulation No 923/2012 does not determine the airspace upper boundaries of the Member States, but the term bead roll defines that the territory of a Member State is overland territories and the adjacent territorial waters, which is in sovereign power or suzerainty, in mandate or protection (EU Regulation Nr. 923/2012, 2012, art.2). EU laws and regulations do not define the airspace upper borders of the Member States, but the regulation is a positive example of mutual harmonization of EU and international law. 


\section{The aspect of territorial jurisdiction of Latvia}

The State as a significant recognition criterion of international legal entity is the ability to ensure efficient control of its territory. As the International Court of Arbitration ascertained in the "Island of Palmas' case (The Island of Palmas Case, 1928), likewise, in the Greenland conflict between Denmark and Norway, in Denmark and Sweden the dispute over the continental shelf, in Finland and Sweden the dispute about Aland Islands (Лунден, 2011, p. 183-190) etc., the principle of territoriality serves both to limit state power in the space and to divide the competence between members of international cooperation (Bojars, 2004, p.305).

National territory is inviolable, resulting from customary international law of many centuries, gaining a written confirmation in Section IV of the Final Act of the Conference on Security and Cooperation in Europe, 1975, determining that the participating States will respect the territorial integrity of each of the participating States and they will refrain from any action inconsistent with the purposes and principles of the Charter of the United Nations against the territorial integrity, political independence or the unity of any participating State, and in particular from any such action constituting a threat or use of force (Grigelonis, 2000, p.109). However, the state power is not exclusive even in its own territory, for example, the United States of America (Bojars, 2010, pp.7180 ) is practising its jurisdiction over foreign commercial enterprises if, in the result of their activities, have been victims of the receiving country, whether the natural or legal persons.

Prof. J.Bojars points out 7 main ways to acquire a national territory: opening of the territory, occupation, growth, voluntary assignment, peace treaties, forced assignment or taking by force (Bojars, 2004, p.296), and we could agree with it, with the exception of the peace treaties, which are in fact the legal act of a territory and thus delimitation, and it can be a legally executed result of any of the above-mentioned forms of taking the territory. In accordance with the self-determination of peoples, rights should be a referable use of the territory since time immemorial antiquitas, vetustas cujus contraria memoria non existit rule, opening of the new territory, a plebiscite, voluntary assignment, territory purchase, renting, giving as a gift and partly the growth path, but in external influence processes are referable - seizure of the territory or its occupation as a result of the use of military force, limitation on benefits and the acquisition of colonies. In conclusion, the determination of the territory, and therefore also the national border, takes place in mutual interaction between peoples' self-determination rights, international relations and political processes, which is the most outstanding 
manifestation of the international legal dispute that fully cover also the Latvian - Russian border (The Border Treaty: Judgment. Material. Comments. 2009, pp.243-248).

In the establishing part of the Constitutional Court judgment, it is shown that the Cabinet of Ministers, referring to the principle of inviolability of borders, has not agreed with the comprehension of Russia about the content of this principle. The Constitutional Court pointed out that Article 3 of the Constitution of the Republic of Latvia has been taken to prevent (difficulty) a possible separation of Latgale from Latvia. Article 3 of the Constitution does not include a constitutional prohibition for Latvia to change the state border, because it is impossible to actually ensure the inviolability of borders in accordance with international law. Also, the Latvian State Border of Latvia has been changed after the entry into force of the Constitution both in the interwar period and after the restoration of independence. Therefore, the border treaty with Russia is not contrary to Article 3 of the Constitution of the Republic of Latvia, since it does not create an interstate border, which amends the defined borders as stipulated in Article 3 of the Constitution in 1922, but records the Latvian-Russian border in accordance with the Treaty at the moment of de jure existing territories of both countries in the written international treaty form (Constitutional Court in the Border Treaty Case Nov 29, 2007, paragraphs 7.2, 7.3). The OSCE Helsinki Final Act confirms the basic principles of interstate relations, including the possibility of amending the boundaries through peaceful means, and sovereign states have the right to enter into any international agreements, including the territory and borders (Written reply of the Cabinet of Ministers to LR Constitutional Court in case No 2007-10-0102, 2007, paragraph 2.6.1.).

The Cabinet of Ministers in its written reply to the Constitutional Court concluded that the facts which had been set out did not create the historical reasons for Abrene's belonging to the Latvian State as a Latvian ethnographic land (Written reply of the Cabinet of Ministers to LR Constitutional Court in case No 2007-10-0102, 2007, paragraph 3.2.4.). However, in the author's point of view, this conclusion is not derived from the answer, the interpretation of the site designation ethnographic principle is analyzed rather controversially in the paper because, at the same time, Abrene's historical and ethnic belonging to Latvians is indicated, confronting it to some of the economic and military-strategic interests in a rather limited period of time, which in fact should not be considered as valid counter-arguments of internationally accepted area and thus the delimitation principles. This is confirmed by Dr. A.Fogelis' assertion that the term "territory of the State" is closely related to the concept of "national territory". In relation to the nation of one state, these 
concepts coincide because the territory of the country is also the nation's living area (Fogels, 2009, p.175). Similar and even radical views were expressed by acting president of the Civil Congress E.Alksnis: „... the adoption of a new border treaty, abandoning a part of the territory of Latvia, is contrary to the Latvian national legal continuity. The adopted rulings of the actual governing body and its officers in the territory of the Republic of Latvia concerning the resignation from the right of a part of the territory of the Republic of Latvia is contrary to Article 3 and Article 77 of the Constitution (The decision on the annexation of Abrene cities and six Abrene district parishes, 1992) and is not valid and not having legal consequences. The abandonment of a part of the territory of the Republic of Latvia in favour of the occupying state is a criminal offense both in accordance with the Punishment Law of the Republic of Latvia and the currently in force Criminal Law of the Republic of Latvia" (Alksnis, 2007).

The proposed analysis in the Constitutional Court judgment about the continuity of the state or continuity doctrine, the State ethnographic aspect of the site designation, the interpretation of the state border irrevocability leads to the conclusion on a clear definition of the need and importance of the national territory. "Fathers" of the Constitution solidified the national sovereignty and national territory in first articles of the Constitution and ensured a mechanism in which both of these elements are mutually protected (The Border Treaty: Judgment. Material. Comments. 2009, Ziemele, p.62). From the grammar interpretation point of view, expressis verbis of Article 3 of the Constitution defines the national territory of Latvia by reference to the specified limits in international agreements and points to two independent theses of structure in Article 3 of the Constitution: first, "The territory of the State of Latvia"... consists of Vidzeme, Latgale, Kurzeme and Zemgale", secondly, [consists] of international agreements, (The Border Treaty: Judgment. Material. Comments.2009, Paparinskis, p.70).

The Border Treaty, which was signed in Moscow, March 27, 2007 with Russia, was adopted and approved by the law in Latvia on May 17, 2007, considering the OSCE principle of inviolability of borders. However, with the judgement of the Constitutional Court, on November 29, 2007, the words "pursuant to the principle of inviolability of borders adopted by the European Security and Cooperation Organization" are recognized as inconsistent with Article 68, the first paragraph of the Constitution and invalid from the date of publication of the judgment (The Law On Treaty of the Republic of Latvia and the Russian Federation on the Latvian and Russian Border, 2007, art.1). 
Nowadays, when all the border treaties of Latvia, with the exception of the marine border treaty with Lithuania, have been contracted, along with development of the International Law of the Sea, there is mainly determined specifically the sea territory of Latvia and there may be defined the airspace of the State with development of the international air law. From the public administration and sovereignty point of view, due to a rather frequent use of the term of national territory in both national and EU law, a specific understanding of the national territory of Latvia is possible. A specific definition of the national territory of Latvia was not possible at the beginning of $20^{\text {th }}$ century - the period of Constitutional acceptance, as indicated by Dr. J.Pleps (The Border Treaty: Judgment. Material. Comments, 2009, Pleps, 2009, pp.129.-135), but it is possible now when it has sufficient doctrinal foundation in contractual rights and international law.

It must be admitted, the issue of Abrene was not analyzed and there was not used precedent experience in international territorial disputes and there had not been reached run-through a dispute in the International Court of Justice (The Border Treaty: Judgment. Material. Comments, 2009, Lēbers, 27.lpp.), although there has been a lot of precedents in international territorial and border disputes in the middle of $20^{\text {th }}$ century (Prescot, 1978, 27, pp.35-40) and also nowadays (Decision of the UN International Court of Justice on the delimitation of the maritime border between Qatar and Bahrain, 2001), including in Europe, such as Denmark - Sweden dispute on the continental shelf (settled by the UN, 1984), Ukraine - Romania dispute about the delimitation of maritime borders (in connection with Snake Island's belonging) in the Black Sea (regulated in 2009), (International Court of Justice Report of Judgements, Advisory Opinions and Orders Maritime Delimitation in the Black Sea (Romania v. Ukraine, 2009), Finland Sweden dispute about the Tana - Tenojoki river (has not been settled so far) (Лунден, 2011, 185 - 186, p. 190).

The UN Charter, the UN Declaration on Principles of International Law (Declaration on Principles of International Law Concerning Friendly Relations and Co-operation among States in accordance with the Charter of the United Nations, 1970), as well as the Vienna Convention on the Law of Treaties, in fact, contains many rules of the international law, which in partly systematized form was created in the period of World War I, in doctrine of the US president T.W.Wilson (Bojars, 2004, p.129), who offered four principles on February 11, 1918, of justice, peace, people's right to territorial integrity, settlement of territorial disputes through treaties and respect for self-determination of peoples internationally. The same year on July 4, T. W.Wilson anticipated these principles in the form 
of four goals, including territory, and thus in the border context: „Each issue of territory, sovereignty, economic agreement or political communication issue need to be solved by adopting settlement on the free agreement of its people, which this agreement directly affected, and not to any other nation or people's interests or preferential basis, which would otherwise use settlement of its external impact or majeure" (Seskis, 1991, p.154). Thus, at the beginning on $20^{\text {th }}$ century Wilson offered the main principles of international law which were included in further laws and regulations contained in second half of $20^{\text {th }}$ century.

\section{Conclusions and suggestions}

Important and noteworthy is the accentuation of the national territory spatial boundaries and their attribution to the form of dimension because the spatial meaning of the phrase "corresponding to this line vertical surface" in the definition of the concept of national borders of the Republic of Latvia, as well as in relevant definitions of other countries is not sufficiently precise due to the fact that the earth is of spherical shape (although it is a slightly stretched in the direction of the equator as a result of the centrifugal force), and the vertical surface of the overlapping state border lines should not be absolutely vertical. In this case, it should be assumed that the country renounces its own significant part of the airspace, but perhaps unreasonably another neighbouring state subsoil space is added. Also, the word 'surface' in the definition of the state border is not accurate, because from the geometric terminology point of view it's a plane or nozzle.

The territory of the State is not only a state border demarcated space in which the State is implementing its power but also the nature of its components - land, water, air space, the depths of the earth and the natural resources that are used in the national economy and are forming the material basis of the territory.

The territory of the State is bounded by land, sea and air borders. The territory of the State is sometimes understood as a land or water surface. But state, setting national borders as well border treaties and national regulatory frameworks, include the concept of national borders within its jurisdiction spread not only in the territory of the surface but also in the spatial sense - the technical capacity of subterranean depth in depths and airspace (100 km above sea level).

In the Latvian National legislative framework with regard to the jurisdiction of marine areas, with determination of the baseline, in use of terms by the Convention on the Law of the Sea ("inland and sea waters", "inland sea waters", "sea waters"), there are several deficiencies in the 
concept, terminological inaccuracies and even contradictions with the Convention on the Law of the Sea.

With regard to the Latvian national sovereignty and jurisdictional issues in the Baltic Sea, the contiguous zone is a topical issue, which is designed as a separate legal term in the Convention on the Law of the Sea. The contiguous zone cannot be extended to the territory that lies further than $24 \mathrm{~nm}$ from the baseline from which a breadth of the territorial sea is measured. However, the contiguous zone is referred to and is defined neither in the Law on the State Border nor in the Marine Environment Protection and Management Law, consequently, it is also not intended for the competence of the public administrations in the implementation of the Latvian jurisdiction (thus sovereignty) in the contiguous zone.

From the grammar interpretation point of view, expressis verbis of Article 3 of the Constitution defines the national territory of Latvia by reference to the specified limits in international agreements and points to two independent theses of structure in Article 3 of the Constitution: firstly, "The territory of the State of Latvia"... consists of Vidzeme, Latgale, Kurzeme and Zemgale ", secondly, [consists] of international agreements.

Nowadays, all the border treaties of Latvia, with the exception of marine areas border treaty with Lithuania, have been contracted. Along with development of the International Law of the Sea, there is mainly determined specifically the sea territory of Latvia and there may be defined the airspace of the State with development of the international air law. From the public administration and sovereignty point of view, due to a rather often use of the term of national territory in both national and EU law, a specific understanding of the national territory of Latvia is possible. A specific definition of the national territory of Latvia was not possible at the beginning of $20^{\text {th }}$ century - the period of Constitutional acceptance, as indicated by Dr. J.Pleps, but it is possible now when it has sufficient doctrinal foundation in contractual rights and international law.

Consequently, the territory of Latvia is the Latvian state border surrounded by land, subterranean depths, internal waters, the territorial sea and airspace $100 \mathrm{~km}$ above sea level. Within its borders (and in certain cases also beyond its) the State performs its territorial supreme command, which is one of the elements of sovereignty.

The author explored the international legal framework for determining the spatial boundary of the national territory. As a result, the author proved the hypothesis and offered a specific definition of national territory of the Republic of Latvia as international legal subject. If this definition of national territory would be included in the national 
regulatory framework, it will contribute the sovereignty and security of international relations.

\section{References}

Laws and regulations:

1. Latvijas Republikas Satversme [The Constitution of the Republic of Latvia]. Retrieved 22.03.2015. from http://www.likumi.lv/doc.php?id=57980

2. Nolīgums par 1982.gada 10.decembra Apvienoto Nāciju Jūras tiesību konvencijas ìstenošanu attiecībā uz transzonālo zivju krājumu un tālu migrējošo zivju krājumu saglabāšanu un pārvaldību[Agreement for the implementation of the provisions of the United Nations Convention on the Law of the Sea of 10 December 1982 relating to the conservation and management of straddling fish stocks and highly migratory fish stocks]. Latvijas Vestnesis, 2006. 8.nov., nr.179. Retrieved 24.03.2015. from http://likumi.lv/doc.php?id=147480

3. Atvērto debesu lïgums[Treaty on open Skies]24.03.1992. Latvijas Vestnesis, 2002. 13.nov., nr.165. Retrieved 2.04.2015. from http://likumi.lv/ doc.php?id=68338

4. ANO Jüras tiesību konvencija[United Nations Cinvention on the Law of the Sea, 1982].Latvijas Vestnesis,2004. 17.nov., nr.183.Retrieved 28.03.2015. from http://likumi.lv/doc.php?id=207737

5. 1975.gada Helsinku Eiropas Drošỉbas un sadarbības apspriedes Nobeiguma akta Deklarācija par principiem, pēc kādiem dalībvalstis vadīsies savstarpējās attiecībās[ Final Act, 1975 Conference on Security and Co-operation in Europe] Iss: GRIGELONIS, J. (2000).Mūsdienu starptautiskās un tirdzniecības tiesības. Starptautiskais civilprocess [Modernandinternationaltrade law. international Civil Procedure]. Riga: AGB, 109p.

6. Starptautiskā konvencija par cilvēku dzīvības aizsardzību uz jūras [International Convention for the Safety of Life at Sea, as amended 1974, (SOLAS-74]Latvijas Vestnesis, 2007, 12.dec., nr.199. Retrieved 2.04.2015. from http://likumi.lv/ doc.php?id=23044

7. Declaration on Principles of International Law Concerning Friendly Relations and Co-operation among States in accordance with the Charter of the United Nations, G.A. res. 2625, Annex, 25 UN GAOR, Supp. (No. 28), U.N. Doc. A/5217 at 121 (1970). 24 October 1970. Retrieved 29.03.2015. from http://www1.umn.edu/ humanrts/instree/principles1970.html

8. Convention on International Civil Aviation (ICAO Convention). Done at: Chicago. Date enacted: 1944-12-07. In force: 1947-04-04. Retrieved 5.04.2015. from: http://www.jus.uio.no/english/services/library/treaties/07/7-

01/international-civil-aviation.xml\#treaty-header1-1

9. Commission Implementing Regulation(EU) No. 923/2012(26 September 2012), laying downcommonrules of the airand operatingrulesand proceduresfor air navigation servicesand amendingImplementing Regulation (EU) No. 1035/2011 and Regulation (EC)No. 1265/2007, (EC) No. 1794/2006, (EC) No. 730/2006, (EC) No. 1033/2006and(EU) No. 255/2010(1). Retrieved 5.04.2015. from http://eur-lex.europa.eu/LexUriServ/LexUriServ.do?uri=0J:L:2012:281:0001: 0066:LV:PDF 
10. Jūras vides aizsardzības un pārvaldības likums [Marine Environment Protection and Management Law]. Latvian law.Latvijas Vestnesis,2010. 28.okt., nr.183. Retrieved 8.04.2015. from http://likumi.lv/doc.php?id=221385

11. Latvijas Republikas valsts robežas likums[Law On the State Border of the Republic of Latvia]]. Latvian law.Latvijas Vestnesis, 2009. 2.dec., nr.189. Retrieved 9.04.2015. from http://likumi.lv/doc.php?id=201364

12. Nacionālo bruñoto spēku likums[National Armed Forces Law] Latvian law. Latvijas Vestnesis, 1999. 24.nov., nr.388/389. Retrieved 5.04.2015. from http://likumi.lv/doc.php?id=15836 [skatìts 05.04.2015.].

13. Par zemes dzīlēm [Law On Subterranean Depths] Latvian law. Latvijas Vestnesis, 1996. 4.jūn., nr.87. Retrieved 8.04.2015. from http://likumi.lv/ doc.php?id=40249

14. Par aviāciju [Law On Aviation]. Latvian law.Latvijas Vestnesis,1994. 20.okt., nr.123. Retrieved 9.04.2015. from http://likumi.lv/doc.php?id=57659

15. Par Latvijas Republikas un Krievijas Federācijas lïgumu par Latvijas un Krievijas valsts robežu [The Law On Treaty of the republic of Latvia and the Russian Federation of the Latvian and Russian Border]. Latvijas Vestnesis, 2007. 29.maijs, nr.85.

16. Par Abrenes pilsētas un sešu Abrenes apriṇka pagastu aneksijas neatzī̌̆anu [The decision on Abrenes cities and six Abrene district parishes annexation]. Latvian republic decision. Retrieved 2.04.2015. from http://www.likumi.lv/ doc.php?id=72436

Legal Practice materials:

17. Internationale Court of Justice Report of Judgements, advisory Jpinions and Orders Maritime Delimitation in the Black Sea (Romania v. Ukraine). Judgement of 3 february 2009. Retrieved 9.04.2015. from http://www.icj-cij.org/docket/files/ 132/14693.pdf

18. „ANO Starptautiskās tiesas lēmums par sauszemes un jūras robežu strīdu starp Kamerūnu un Nigēriju 1998.g. 11.jūnijā; ANO Starptautiskās tiesas lēmums par jūras robežas delimitāciju starp Kataru un Bahreinu 2001.g. 16.martā u. c.” ANO Starptautiskās tiesas lēmumu, konsultatīvo slēdzienu un secinājumu izdevums par [edition of UN International Court of Justice decisions, advisory opinion and conclusions] 1997-2002. g. ST/LEG/SER.F/1/Add.2. Retrieved 12.04.2015.from http://www.icj-cij.org/homepage/ru/files/sum_1997-2002.pdf

19. Permanent Court of Arbitration. The Island of Palmas Case (or Miangas). Award of the Tribunal. The Hague, 4 april 1928. Retrieved 12.04.2015. from http://untreaty.un.org/cod/riaa/cases/vol_ii/829-871.pdf

20. Satversmes tiesas 2007.gada 29.nov. spriedums [Judgement by the Constitutional Court Nov 29, 2007] "Par likuma "Par pilnvarojumu Ministru kabinetam parakstīt 1997. gada 7. augustā parafēto Latvijas Republikas un Krievijas Federācijas līguma projektu par Latvijas un Krievijas valsts robežu" un likuma "Par Latvijas Republikas un Krievijas Federācijas līgumu par Latvijas un Krievijas valsts robežu" 1. panta vārdu "ievērojot Eiropas Drošības un sadarbības organizācijas pieṇemto robežu nemainības principu" atbilstību Latvijas PSR Augstākās padomes 1990. gada 4. maija deklarācijas "Par Latvijas Republikas neatkarības atjaunošanu" preambulai un 9. punktam un 2007. gada 27. martā parakstītā Latvijas Republikas un Krievijas Federācijas līguma par Latvijas un Krievijas valsts robežu un likuma "Par Latvijas Republikas un Krievijas Federācijas līgumu par Latvijas un Krievijas valsts robežu" atbilstību 
Latvijas Republikas Satversmes 3. pantam". Retrieved 6.04.2015. from http://likumi.lv/doc.php?id=167214

21. LR Satversmes Tiesai, Lieta Nr.2007-10-0102 [Constitutional Court of the Republic of Latvia, Case No. 2007-10-0102]. Par likuma „Par pilnvarojumu Ministru kabinetam parakstīt 1997.gada 7.augustā parafēto Latvijas Republikas un Krievijas Federācijas līguma projektu par Latvijas un Krievijas valsts robežu" atbilstību Latvijas Republikas Augstākās padomes 1990.gada 4.maija deklarācijas „Par Latvijas Republikas neatkarības atjaunošanu” preambulai un 9.punktam un par 2007.gada 27.martā parakstītā Latvijas un Krievijas robežlīguma atbilstību LR Satversmes 3.pantam - MK Atbildes raksts LR Satversmes Tiesai Lietā Nr.2007-10-0102). Latvijas Vestnsis, 2007. 30.nov., nr.193.

Books and articles:

22. BOJĀRS, J. (2010). Starptautiskās privāttiesības[Private International Law] II. Riga: Zvaigzne ABC, 423 p.

23. BOJĀRS, J. (2004). Starptautiskās publiskās tiesības [Public International Law] I. 3.pārstr. izdev. Riga: Zvaigzne ABC, 754 p.

24. BOJĀRS, J. (2004).Starptautiskās publiskās tiesības[Public International Law]II. Riga: Zvaigzne ABC, 844p.

25. ZIPELIUSS, R. (1998). Vispārējā mācība par valsti [The general lesson about the country]. Riga: AGB, 355p.

26. FOGELS, A. (2009). Modernās starptautiskās tiesības [Modern international law]. Riga: Zvaigzne ABC, 294 p.

27. Robežlīgums: Spriedums. Materiāli. Komentāri (2009), [The Border Treaty: Judgment. Material. Comments] Riga: Latvijas Vestnesis, 640 p.

28. SESKIS, J. (1991). Latvijas valsts izcelšanās pasaules kara notikumu norisē. Atminnas un apcerējumi [Latvian national outbreak of World War II in the course of events. Memory and essays] (1914.-1921.). Riga: Sabiedrības „Balta” gramatu apgads, Rigas paraugtipografija, 344p.

29. CEPURNIECE, S., GUTMANIS, G., LUKSTINS, V. (1969). Svešvārdu vārdnīca [Dictionary of Foreign Words]. Riga: Liesma, 702 p.

30. ALKSNIS, E. Pazinojums par Latvijas-Krievijas robežu[Communication on the the Latvian-Russian border]. Riga, 24. March,2007.. Retrieved 2.04.2015. from: www.ltn.lv/ pilsonis/doc/\%5Bpilsonis.lv\%5Dpplkr.doc.

31. PRESCOT, J.R.V. (1978). Boundaries and Frontiers. London: Croom Helm Ltd, 210 St. John's Road, , 210 p.

32. Theodore von Kármán (Szőllőskislaki Kármán Tódor) (May 11, 1881 - May 7, 1963) was a Hungarian-Americanmathematician, aerospace engineer and physicist who was active primarily in the fields of aeronautics and astronautics. Iss: Thread of the Silkworm. Perseus Books Group (1995). The International Air Sports Federation. Retrieved 6.04.2015. from http://www.fai.org/icarerecords $/ 100 \mathrm{~km}$-altitude-boundary

33. ЛУНДЕН,Т. (2011). Конфликты по вопросам границ. Северная Европа, проблемы истории [Conflictsoverboundaries. Northern Europe, the problems of history]. (ред. Чернышева O.В., Комаров А.А.). Российская Академия наук. Москва: Наука, 456 с.

34. КАПУСТИН, М. (2007). Международное право: Конспект лекций, 1873 год [Internationallaw: Lectures, 1873]. Золотой фонд Российской науки международного права. Том 1. Москва: Международные отношения, 338 с. 


\title{
LATVIJAS VALSTS KĀ STARPTAUTISKO TIESĪBU SUBJEKTA TELPISKAIS IETVARS \\ Artūrs GAVEIKA
}

\author{
Dr.iur, Rēzeknes Augstskolas, Ekonomikas un pārvaldības fakultātes docents, \\ Rēzekne, Latvija
}

\section{Kopsavilkums}

Pētījuma aktualitāte saistīta ar valsts teritorijas jēdziena precīzāku un skaidrāku definēšanu nacionālajā normatīvajā regulējumā. Pētījuma mērḳis ir izpētīt mūsdienu starptautisko normatīvo regulējumu un tiesu praksi valsts teritorijas jēdziena dziḷākai izpratnei, iniciējot diskusiju par šĩ jēdziena harmonizāciju nacionālajā normatīvajā regulējumā. Pētījumā ir izmantotas šādas pētniecības metodes: a) sistēmiskā metode b) gramatiskā metode; c) vēsturiskā metode; d) analīzes metode; e) teleologiskā metode. Pētījuma hipotēze: ja Latvijas kā starptautisko tiesību subjekta valsts teritorija tiks konkrēti definēta nacionālajā normatīvajā regulējumā, tas sekmēs valsts suverenitāti un drošību starptautiskajās attiecībās.

Termins „valsts teritorija” bieži sastopams starptautiskajā, Eiropas Savienības un nacionālajā normatīvajā regulējumā. No gramatiskās interpretācijas viedokḷa Satversmes 3.pants expressis verbis definē Latvijas valsts teritoriju ar atsauci uz starptautiskajos līgumos noteiktajām robežām un norāda uz Satversmes 3.panta struktūras divām neatkarīgajām tēzēm: pirmkārt, „Latvijas valsts teritoriju.. sastāda Vidzeme, Latgale, Kurzeme un Zemgale"; otrkārt, [sastāda] starptautiskos līgumos noteiktās robežās.

Mūsdienās Latvijai visi robežlīgumi ar kaimiṇvalstīm ir noslēgti, izṇemot jūras teritoriju robežlīgumu ar Lietuvu. Līdz ar Starptautisko jūras tiesību attīstību lielākoties ir konkrēti noteikta Latvijas teritoriālā jūra un ar starptautisko gaisa tiesību attīstību var tikt noteikta arī valsts gaisa telpa (augšējā robeža līdz 100 km virs jūras līmen,a - Karmana līnija).

No valsts pārvaldes un suverenitātes nodrošināšanas viedokḷa un sakarā ar valsts teritorijas termina biežo lietojumu gan nacionālajās, gan Eiropas Savienības tiesībās, ir iespējama Latvijas valsts teritorijas konkrētāka izpratne. Konkrēta Latvijas valsts teritorijas definēšana nebija iespējama 20.gs sākumā Satversmes pieṇemšanas periodā, bet ir iespējama tagad, kad tam ir pietiekams Latvijas līgumtiesību un starptautisko tiesību doktrinālais pamats.

Latvijas teritorija ir Latvijas Republikas valsts robežas ieskauta sauszeme, zemes dzīles, iekšējie ūdeņi, teritoriālā jūra un gaisa telpa virs tiem. Šajā telpā Latvijas Republika ir suverēna un izplata savu jurisdikciju saskaṇā ar starptautiskajiem un nacionālajiem tiesību aktiem. Savas teritorijas robežās (jūras teritorijās - arī ārpus teritoriālās jūras) valsts îsteno savu teritoriālo virsvadību, kas ir viens no suverenitātes elementiem.

Atslēgas vārdi: valsts teritorija, gaisa telpa, teritoriālā jūra, zemes dzīles, jurisdikcija. 